https://doi.org/10.31470/2706-7904-2021-16-303-307

\title{
POSITIVE EFFECTS OF FEMALE STEREOTYPES FUNCTIONING (ILLUSTRATED BY THE CASE OF THE UKRAINIAN MILITARY NON-INSTITUTIONAL DISCOURSE)
}

Положительные эффекты функционирования женских стереотипов (на примере украинского военного неинституционального дискурса)

\section{Tetyana Khraban}

\section{Ph.D. in Philology}

Military Institute of Telecommunications and Information Technologies (Ukraine)

Xraban.Tatyana@gmail.com

https://orcid.org/0000-0001-5169-5170

\begin{abstract}
The abstract reveals effects of female stereotypes functioning. Studying the gender stereotype's psychological and social functions, we have noted the following positive effects of female stereotypes functioning in the Armed Forces of Ukraine: (1) destruction of gender typology, overcoming polarization between femininity and masculinity as polar opposite genders; (2) changing the vector of gender priorities from the predominance of belonging to certain gender to the predominance of belonging to the corporate military culture; that makes it crucial to perceive and evaluate a woman, first of all, as a representative of military professional activity; (3) creation of psychological prerequisites for the prevalence of a positive emotional state in the military collective and formation of communication principles characterized by empathy.
\end{abstract}

Key words: gender stereotype, discourse analysis, female stereotypes, armed forces.

\section{Introduction}

Bcmyn

The total number of women in the Armed Forces of Ukraine is growing (women represent 15 per cent of the military, 902 women have senior officer ranks as of March 2020; two women in Ukraine achieved the rank of major general as of August 2020) (Order of the Cabinet of Ministers of Ukraine of October 28, 2020 № 1544-r). Women are enrolled on equal terms with men in the military higher educational institutions where they can acquire specialties, according to which they can serve in the army as officers. In this regard, studying of gender stereotyping and gender role formation in the Armed Forces of Ukraine can contribute to the development of desirable options of female representation in armed services. 


\section{Methods and Techniques of the Research Методи і методики дослідження}

The focus on achieving the most efficient results in studying of modern Ukrainian military non-institutional discourse requires consideration of discourse analysis as the main methodological approach. The discursive approach for research studies on gender stereotypes in the Armed Forces of Ukraine is consistent with an emerging trend in practice and doctrine that draw a researcher's attention to a real person and life situations. The material for our empirical research are text fragments and photographs that are posted on the website of "Military service" Ukrainian group.

\section{Results \\ Результати}

First of all, it should be mentioned that military personnel often deal with a situation of uncertainty, instability and increased danger as part of their work. In order to understand the situation and decide how to handle it, serviceman turns to stereotyping. Meanwhile, the cognitive-adaptive function becomes active and aims at simplifying and systematizing the knowledge received by the individual from the environment, thereby serves to save the individual's efforts in the perception of complex phenomena. The consistent and clear appreciation of the situation can be got through a cognitive gender metaphor. On the one hand, cognitive gender metaphors are "a peculiar way of creating stereotypical structures of beliefs, as they can implicitly offer people a frame to interpret the social world from a specific perspective. However, on the other, metaphors might also be a tool to challenge tacitly shared stereotypical knowledge by offering a new perspective which reveals previous strategies of framing" (Ervas, 2017). In the example of feminine metaphorical representation of the $12.7 \mathrm{~mm}$ DShK heavy machinegun, namely "Dashka" (Dashka is a Ukrainian feminine given name, often a nickname for Daria) the entirety of spiritual, intellectual and emotional properties united by the semantic component 'femininity' is attributed to an inanimate object. In this case, the feminine metaphor uses the whole range of associations with woman to actualize the socio-psychological characteristics of woman: sensitivity, rapid change in emotional states, susceptibility, emotionality, vulnerability, hysteria, capriciousness. Thus, in the feminine metaphor structure we identify traditional female stereotypes as non-reflective images that nevertheless exist and form the cognitive model of woman in the minds of military men. However, the presence in the text of verbal signs of integration (lexical category of fraternity, words with the connotation 'we', evaluative words) demonstrates not only the absence of polarization, but also the trust and support between man and woman in a military corporate culture. The purpose of value- 
protective function of gender stereotypes is not only to explain and protect group attitudes and behavior but also to sustain collective values, to justify and rationalize discriminatory attitudes towards an outgroup. It should be noted that gender stereotypes in this example are used not to create the opposition "man - woman" or "male - female", but "military civilian". Contrasting qualities and images of groups are brought into comparison, and the female stereotypes serve as a background on which an own ideal is constructed. Reproducing gender stereotypes this opposition accentuates gender asymmetry, which is based on the component good/bad that is of a value nature. Binarity as one of the basic principles of understanding gender differences is used to aggravate the disparities between social and professional groups. This is achieved through attributing female characteristics to an out-group and accusing it of inconsistency with the stereotype of masculinity. At present gender stereotyping in the Armed Forces of Ukraine becomes flexible, and stereotypes are corrected depending on the social context, for example on the professional activity of the person and the object of stereotyping. Some of the reasons for this are linked with the military professional activity specific, which is that in the army efficiency in accomplishing the assigned tasks is possible only if there is a unified system of corporate goals, values and relations. Gender identification in the Armed Forces of Ukraine turns out to be secondary, but identification with a military professional group becomes urgent. A woman in the Armed Forces of Ukraine, just like a man, becomes the supporter of the ideas and ideals of military professional activity, and the updated gender stereotype includes values and norms promoted by the corporate military culture. While not denying the importance of differences between the sexes for gender stereotyping and gender role formation in the Armed Forces of Ukraine, we nevertheless believe it is the corporate military culture that is becoming the springboard for changes in the female stereotypes and for the gradual smoothing of professional discrimination against women not only in the army, but throughout society. Effective implementation of combat mission is largely determined by the nature of the relationship between the members of the military units. The ability to understand the situation, to coordinate one's behavior in accordance with it, as well as in accordance with the behavior of other people, is a necessary condition for the existence of the military units. Formal (service) relationships in the military units comply strictly with the military statutes and regulations, which formulate the following basic principles: unity of command (authority delegated from only one individual), strict military discipline, subordination. The essence of the unity of command and strict subordination principles is dividing the military into rank groups that correlate with the command and control functions; imposing on superiors to exercise command functions and on subordinates to follow the orders with unquestioning obedience. Within the framework of formal (service) relationships, when personal sympathies and antipathies do not play a central role, female stereotypes in the 
Armed Forces of Ukraine have the potential to ensure consistency in the behavior of military men. The constructive function of gender stereotypes is activated under the impact of a specific military socio-psychological environment and is aimed at adoption the military men's beliefs and world view by every serviceman. The psychological category "adoption" is a multifaceted concept that has deep cultural, philosophical, religious and social roots. In this example, in order to have a better comprehending of the military service nature and to correlate the expression of his emotions and his behavior in accordance with it, as well as in accordance with other people's behavior, the individual turns to a simulation model that emphasizes female stereotypes typical of patriarchal culture. In this study a simulation model is considered as a set of parameters, criteria and restrictions (norms, standards), with which the behavior of an individual or a social group is assessed and predicted (Afonin, 2014). Elements of language game, some conventionality of this simulation model favor the emancipation of a serviceman, help to prevent the stress associated with the need to obey in armed forces, and also let adopt the form and manner of behavior in typical social situations that presuppose strict military discipline, subordination and unity of command. On the other hand, such simulation model that involves female stereotypes lets a serviceman perceive and evaluate a woman as a person of the opposite sex based on the characteristics of her inner world and her professional activities. This helps to overcome some barriers in communication, understand an another personality and establish harmonious relationships. Next subject of interest from the perspective of the gender stereotype psychological functions, it is emotional nature of gender stereotypes, when gender identification is aimed at characteristics associated with the process of interpersonal interaction and not with socioprofessional relations. In this case, stereotypes accentuate the feminine charm, softness, the need to nurture. The emotional-evaluative function of female stereotypes lets a military man of the Armed Forces of Ukraine to reproduce situations that are emotionally significant for him, in which his needs for recognition and love have been met. In the future, this can contribute to creation of psychological comfort and deep emotional ties between men and women in a military collective.

\section{Conclusions \\ Висновки}

So, in the Ukrainian military corporate culture, the influence of the female stereotypes on the perception of female military personnel by male military personnel have positive effects, which consist in: (1) destruction of gender typology, overcoming polarization between femininity and masculinity as polar opposite genders, creating relations between representatives of different genders that are based on trust and support; 
(2) changing the vector of gender priorities from the predominance of belonging to certain gender to the predominance of belonging to the corporate military culture; that makes it crucial to perceive and evaluate a woman, first of all, as a representative of military professional activity; (3) creation of psychological prerequisites for the prevalence of a positive emotional state in the military collective and formation of communication principles characterized by empathy.

\section{References}

\section{Лimepamypa}

Afonin, E.A. (2014). Stanovlenie Vooruzhennyh Sil Ukrainy: social'nye i social'nopsihologicheskie problemy [Formation of the Armed Forces of Ukraine: social and socio-psychological problems]. Kiev - Nezhin: NTC «Psiheja».

Ervas, F. (2017). Another metaphor is possible. Challenging social stereotypes in figurative language comprehension. Reti, Saperi, Linguaggi, 4(1), 79-96. https://doi.org/10.12832/87357

Order of the Cabinet of Ministers of Ukraine of October 28, 2020 № 1544-r National Action Plan for the implementation of UN Security Council Resolution 1325 "Women, Peace, Security" for the period up to 2025. Retrieved from https://zakon.rada.gov.ua/laws/show/1544-2020-\%D1\%80\#Text 